\title{
KONTROL SISTEM CHARGING PEMBANGKIT LISTRIK TENAGA BAYU PT. LENTERA BUMI NUSANTARA BERBASIS INTERNET of THINGS (IoT)
}

\author{
Angga Laksana ${ }^{1}$, Sutisna $^{2}$, Firmanysh M S Nursuwars ${ }^{3}$, \\ Teknik Elektro, Fakultas Teknik, Universitas Siliwangi, Tasikmalaya, Indonesia ${ }^{1,2,3}$ \\ Email: 157002098@student.unsil.ac.id ${ }^{3}$
}

\begin{abstract}
Abstrak
PT. Lentera Bumi Nusantara merupakan pusat penelitian turbin angin yang dikembangkan di daerah Cipatujah, Kabupaten Tasikmalaya. Ditempat ini pengembangan sumber energi alam menjadi pusat penelitian, salah satunya yaitu sumber energi listrik angin. Fokus pengembangannya yaitu Pembangkit Listrik Tenaga Bayu skala micro yang diberi nama Wind Luce (YWS-500) disebut juga A-WING. Kontrol sistem charging pembangkit listrik tenaga bayu ini masih dalam tahap pengembangan, dikarenakan dalam kontrol sistem charging untuk baterai masih menggunakan sistem manual yaitu melakukan pengukuran secara langsung ke tempat menggunakan alat ukur digital dan pencatatan. Sehingga, permasalahan yang harus di selesaikan yaitu bagaimana memperoleh data kontrol sistem charging pada baterai dan dapat diakses melalui jarak jauh secara realtime. Metode yang digunakan pada penelitian ini yaitu studi literatur, obsevasi, perancangan sistem, pengumpulan kebutuhan sistem, pengujian unit, perakitan sistem, pengujian sistem, dan menganalisis hasil pengujian. Proses kontrol sistem charging pada pembangkit listrik tenaga bayu ini untuk memperoleh data baterai melalui jarak jauh secara realtime menggunakan sistem online yang terhubung dengan jaringan internet atau menggunakan Internet of Things (IoT) yang nantinya data dapat diketahui dengan mudah. Hasil dari pengujian kontrol sistem charging ini memiliki nilai maksimum dan minimum pada setiap besaran listrik yang terukur oleh kontrol sistem charging. Pada charging measurement mempunyai nilai tegangan maksimum sebesar 26,65 Volt dan minimumnya sebesar 23,92 Volt sedangkan nilai charging current maksimum sebesar 7,77Ampere. Kemudian untuk charging power memiliki 3 nilai yaitu nilai Average Charging Wattage 24,48 Watt, nilai Maximum Charging Wattage 206,15 Watt dan Obtained Power 587,32 wh. Kontrol ini dapat memperoleh data kontrol sistem charging pada baterai wind turbine secara realtime melalui jarak jauh. Sehingga, pembuatan kontrol sistem charging ini lebih memudahkan dalam melakukan kontrol pada baterai dengan tampilan yang disajikan pada website dan display LCD, dengan menggunakan ESP32 sebagai pengolah data serta sebagai penghubung ke jaringan internet.
\end{abstract}

Kata Kunci: Baterai, Internet, Kincir Angin, Kontrol Sistem Charging.

\begin{abstract}
PT. Lentera Bumi Nusantara is a wind turbine research center developed in the Cipatujah area, Tasikmalaya Regency. In this place the development of natural energy sources becomes a research center, one of which is a source of wind electrical energy. The focus of its development is a micro-scale Wind Power Plant named Wind Luce (YWS-500) also known as AWING. The control of the charging system for this wind power plant is still in the development stage, because the control of the charging system for charging the battery is still using a manual system, namely taking measurements directly to the place using digital measuring instruments and recording. Thus, the problem that must be solved is how to obtain control data of the charging system on battery charging and can be accessed remotely in realtime. The methods used in this research are literature study, observation, system design, system requirement collection, unit testing, system assembly, system testing, and analyzing test results. The process of controlling the charging system at this wind power plant is to obtain battery charging data remotely in real time using an online system that is connected to the internet network or using the Internet of Things (IoT) which later data can be easily identified. The results of this charging system control test have a maximum and minimum value for each electric quantity measured by the charging system control. The charging measurement has a maximum voltage value of 26.65 Volts and a minimum of 23.92 Volts while the maximum charging current value is 7.77 Ampere. Then for charging power it has 3 values, namely the Average Charging Wattage value of 24.48 Watt, the Maximum Charging Wattage value of 206.15 Watt and Obtained Power 587.32 wh. This control can obtain the charging system control data on the wind turbine battery charging in real time remotely. Thus, making this charging system control makes it easier to control battery charging with the display presented on the website and LCD display, using ESP32 as a data processor and as a liaison to the internet network..
\end{abstract}

Keywords: Battery, Control System Charging, Internet of Things, Wind Turbine.

\section{PENDAHULUAN}

PT. Lentera Bumi Nusantara merupakan salah satu perusahaan hasil karya anak bangsa Indonesia yang bernama Ricky Elson. Ditempat ini pengembangan sumber energi alam menjadi pusat penelitian, salah satunya yaitu sumber energi listrik alternatif angin dan matahari. Dimana yang menjadi fokus pengembangannya adalah PLTB (Pembangkit Listrik Tenaga Bayu). Pembangkit Listrik Tenaga Bayu skala micro ini diberi nama Wind Luce (YWS-500) disebut juga A-WING. Potensi energi angin tersebut cukup memadai karena dibagian selatan jawa barat ini atau kabupaten tasikmalaya lebih tepatnya yaitu Pantai Selatan Ciheras, 
kecamatan Cipatujah, kabupaten Tasikmalaya, Jawa Barat. mempunyai Potensi kecepatan $5 \mathrm{~s} / \mathrm{d} 12 \mathrm{~m} / \mathrm{s}$ sangat layak untuk manfaatkan sebagai sumber energi [1]. Selain dari pada pembangkit listrik tenaga angin yang sedang di kembangkan. Teknologi informasi dan komunikasi juga mulai diberkembang ditempat ini. Dimana teknologi informasi dan komunikasi terkini adalah Internet of Things (IoT). Internet of Things merupakan teknologi yang memanfaat konektivitas jaringan internet yang tersambung secara terus-menerus. Kemampuannya yaitu serbagi pengontrol sistem data yang nantinya berhubungan dengan website.

Permasalahan yang terdapat di PT. Lentera Bumi Nusantara yaitu, kontrol sistem charging yang dilakukan masih secara rutin menggunakan cara manual dengan melakukan pengukuran menggunakan alat ukur dan pencatatan secara langsung serta data yang didapat belum bisa diketahui nilai charging pada baterai selama 24 jam. Sehingga, kontrol sistem charging pada baterai terbatas dan data yang didapat cukup lama karena untuk pengukuran harus datang ke tempat charging. Data yang dikontrol berupa tegangan, arus dan daya yang masuk pada baterai. Untuk mempermudah dalam memperoleh data sistem charging yang terukur pada baterai cukup dengan menggunakan laptop dan smartphone yang terhubung melalui jaringan internet dengan memasukan kode alamat website yang terdaftar pada kontrol sistem charging maka data tersebut akan tampil dan mudah untuk diperoleh. Melalui sistem online ini data yang didapat akan lebih mudah dalam memperoleh data pada baterai secara realtime ataupun secara offline dengan cara mengambil data pada micro SD, dengan adanya kontrol sistem charging maka baterai akan bertahan lama / tidak cepat rusak.

Berdasarkan hal-hal tersebut penelitian ini betujuan ikut serta dalam pengembangan Pembangkit Listrik Tenaga Bayu di PT. Lentera Bumi Nusantara dengan judul "Kontrol Sistem Charging Pembangkit Listrik Tenaga Bayu PT. Lentera Bumi Nusantara Berbasis Internet of Things (IoT)" dengan terkontrol sistem charging pada baterai wind turbine secara realtime melalui jarak jauh menggunakan Internet of Things (IoT).

\section{KAJIAN PUSTAKA}

\section{A. Pembangkit Listrik Tenaga Bayu (PLTB)}

Pembangkit Listrik Tenaga Bayu (PLTB) adalah suatu pembangkit listrik yang menggunakan angin sebagai sumber energi untuk menghasilkan energi listrik. Pembangkit ini dapat mengkonversikan energi angin menjadi energi listrik dengan menggunakan turbin angin atau turbin angin. Sistem pembangkit listrik menggunakan angin sebagai sumber energinya. energi alternatif ini berkembang sangat pesat, mengingat angin merupakan salah satu energi yang tidak terbatas di alam [2]. Sebagaimana telah diketahui, angin merupakan udara yang bergerak dari tekanan udara yang lebih tinggi ke tekanan udara yang lebih rendah. Perbedaan tekanan udara disebabkan oleh perbedaan suhu udara akibat pemanasan atmosfir yang tidak merata oleh sinar matahari. Karena bergerak angin memiliki energi kinetik.

\section{B. Jenis Wind Turbine}

1) Wind turbine poros horizontal

Gbr 1, merupakan Turbin poros horizontal yang memiliki shaft rotor dan generator pada puncak tower dan harus diarahkan ke arah angin bertiup [3].

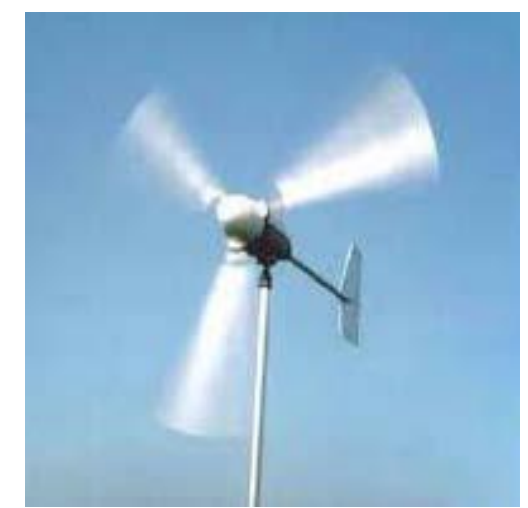

Gbr 1. Wind Turbine Poros Horizontal

\section{2) Wind turbine poros vertical}

Gbr 2, merupakan turbin poros vertikal. Wind turbine jenis ini memiliki bilah yang memanjang. Turbin poros vertical biasanya berdiri setinggi 100 meter dengan lebar 50 kaki dengan sumbu vertical [4].

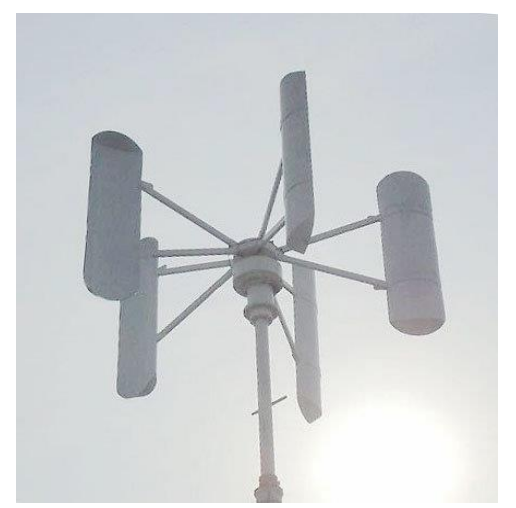

Gbr 2. Wind Turbine Poros Vertical

1) Wind Turbine

Gbr 3, merupakan Wind Turbine sebagai alat konversi energi angin menjadi energi mekanik. Energi angin $\left(\mathrm{P}_{\text {wind }}\right)$ merupakan hasil dari setengah kali masa jenis udara $(p)$ dengan luas penampang turbin angin (A) dan pangkat tiga dari kecepatan angin $\left(\mathrm{V}^{3}\right)[1]$.

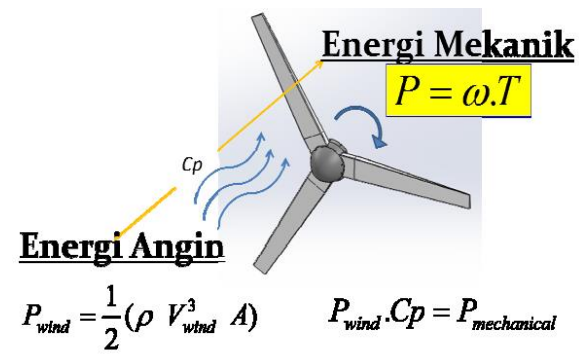

Gbr 3. Wind Turbine 


\section{2) Controller}

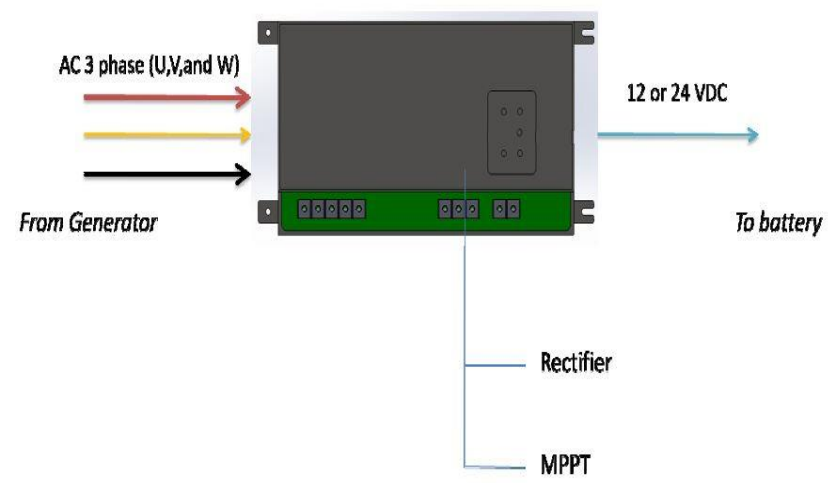

Gbr 4. Controller

Gbr 4, merupakan Controller yang berfungsi untuk meneyearahkan tegangan AC menjadi tegangan DC karena hasil pemprosesan rangkaian voltage detector ini harus berupa tegangan DC selain menyearahkan controller ini juga untuk menurunkan tgangan yang nantinya masuk ke baterai [5]. Sehingga, controller ini sangat dibutuhkan dalam pembangkit tenaga bayu.

\section{3) Baterai}

Gbr 5, merupakan baterai sebagai media penyimpanan energi listrik. Pada pengisian baterai terjadi reaksi elektrokimia charging dan discharging. Proses charging ini bekerja saat baterai berfungsi sebagai baban dan sumber energinya dari generator, sementara itu proses discharging adalah ketika baterai menjadi sumber energi untuk pengisian beban lainnya (misalnya lampu).

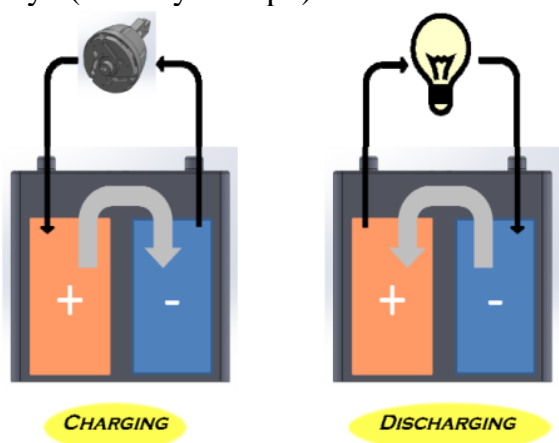

Gbr 5. Baterai

\section{4) Internet of things (IoT)}

Internet of Things (IoT) tempat pengontrolan dan peralatan pemantauan untuk mendukung kebutuhan manusia berdasarkan teknologi internet [6]. Internet of Things (IoT) umumnya mengacu pada jaringan interkoneksi antar perangkat sehari-hari yang seringkali dilengkapi dengan kecerdasan untuk mendukung berbagai macam kendali dan pemantauan [7]. Tiga bagian utama pada arsitektur Internet of Things (IoT) Barang Fisik yang dilengkapi modul IoT, Perangkat koneksi ke Internet seperti Modem dan Router Wireless Speedy seperti di rumah anda, dan Cloud Data Center tempat untuk menyimpan aplikasi beserta data base [8], pada Gbr 6, merupakan arsitektur Internet of Things (IoT).

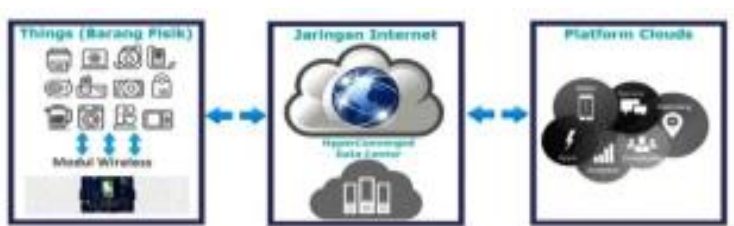

Gbr 6. Internet Of Things (IoT)

\section{METODE}

A. Diagram Alur Penelitian

Gbr 7, merupakan diagram alur yang menjelaskan tahapan penelitian Implementasi kontrol sistem charging pada baterai.

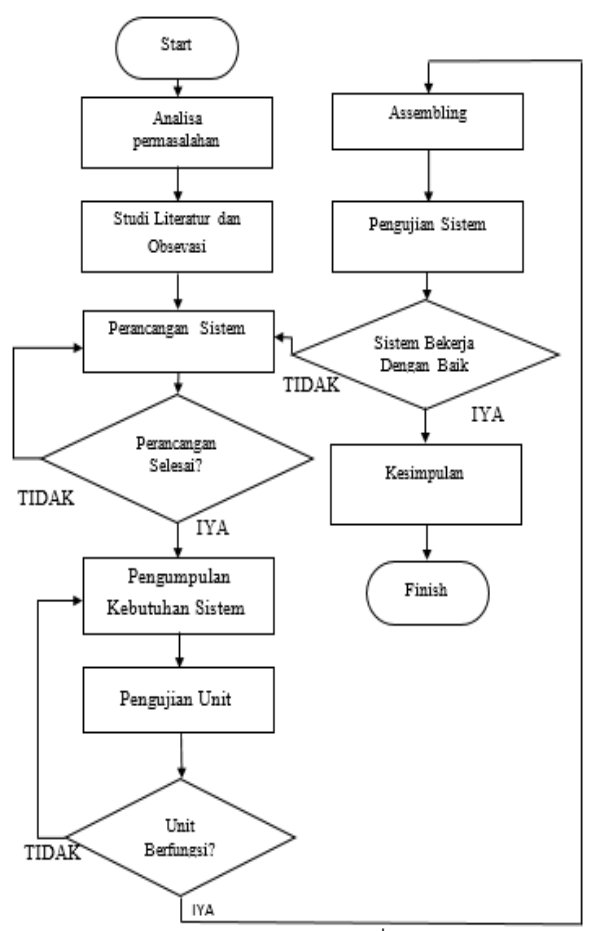

Gbr 7. Diagram Alur Penelitian

1) Perencanaan Sistem Wind Turbine

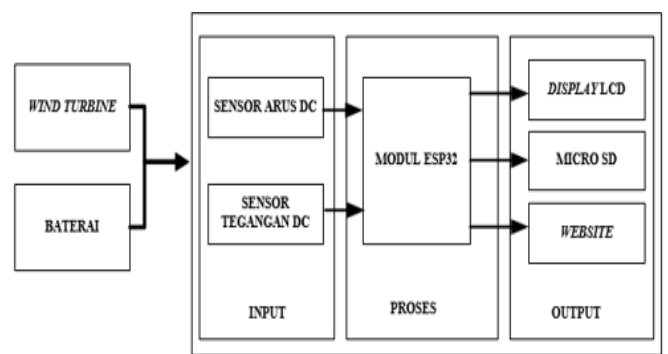

Gbr 8. diagram Block Kontrol Sistem Charging

Gbr 8, merupakan diagram block sistem, yang terdiri dari input yang berfungsi sebagai pembacaan data yang akan diolah oleh esp32, kemudian lanjut ke proses dimana esp32 akan memprose data yang terbaca oleh sensor, setelah itu masuk ke output data akan ditampilkan melalui lcd, micro sd, dan website. 
2) Rencana Perangkat Keras Kontrol Sistem Charging

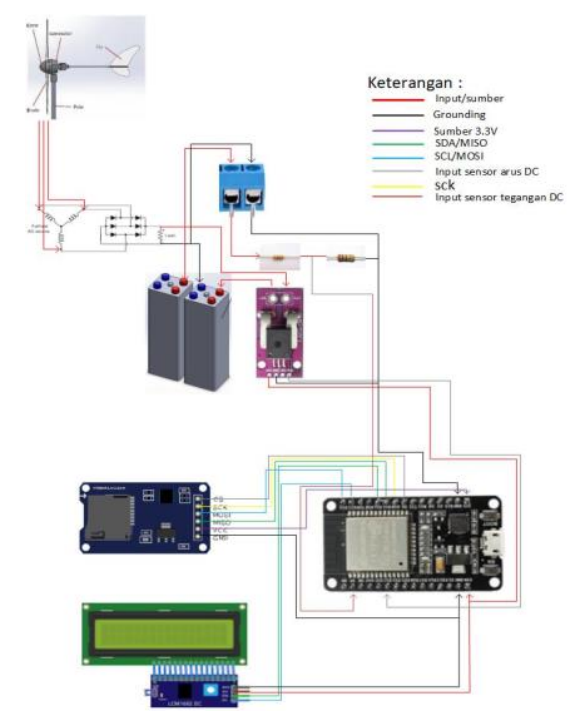

Gbr 9. Skematik Perancangan Hadware

Gbr 9, merupakan skematik perancangan hardware dari kontrol sistem charging pembangkit listrik tenaga bayu, yang bertujuan untuk mengetahui komponen apa saja yang dibutuhkan dalam pembuatan sistem yang dirancang.

\section{HASIL DAN PEMBAHASAN}

\section{A. Diagram Alur Sistem}

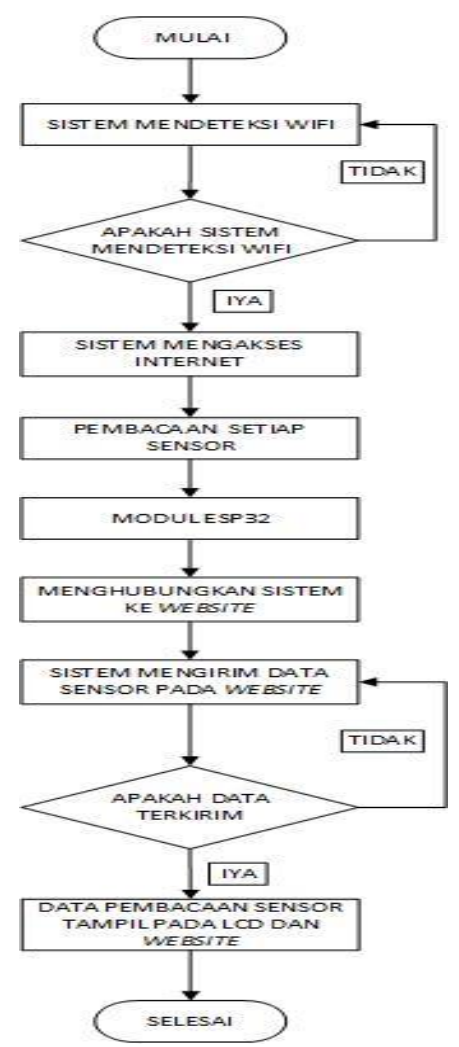

Gbr 10. Diagram Alur Sistem

Gbr 10, berisi diagram alur dari sistem yang dibuat, dimulai dari sistem dalam keadaan mati, ketika sistem dinyalakan maka sistem akan bekerja dan akan mulai terhubung dengan koneksi internet maka kontrol sistem charging akan terhubung dengan wifi. Setelah itu sistem akan mengecek sensor apa saja yang terpasang, lalu data sensor yang terpasang akan dikirimkan ke website. Sistem akan mengecek apakah data sudah terkirim atau belum, jika sudah maka data berhasil diterima oleh website.

\section{B. Pengujian Unit}

Pengujian unit ini bertujuan untuk mengetahui apakah komponen ini dapat berfungsi dengan baik. Sehingga bisa di gunakan pada sistem. Ada beberapa komponen yang di uji.

\section{1) Pengujian Modul Esp32}

Gbr 11, merupakan hasil pengujian setelah potensio $10 \mathrm{k}$ diputar full. Dari putaran tersebut, maka esp32 mempunyai nilai analog sebesar 4095 .

\section{Nilai Anaolog}

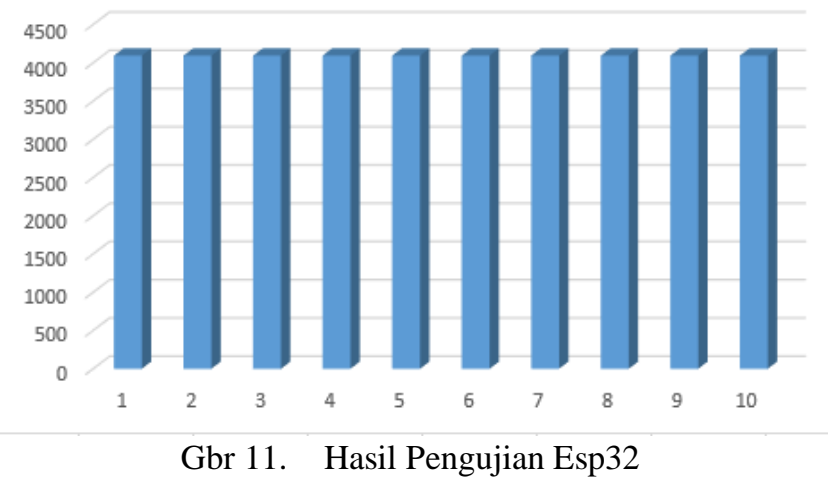

2) Pengujian LCD

Gbr 12, Menunjukan bahwa pengujian pada LCD 20x4 sesuai dengan instruksi yang telah diinstruksikan. Sehingga, bisa dikatakan berjalan dengan baik dan tidak ada kendala.

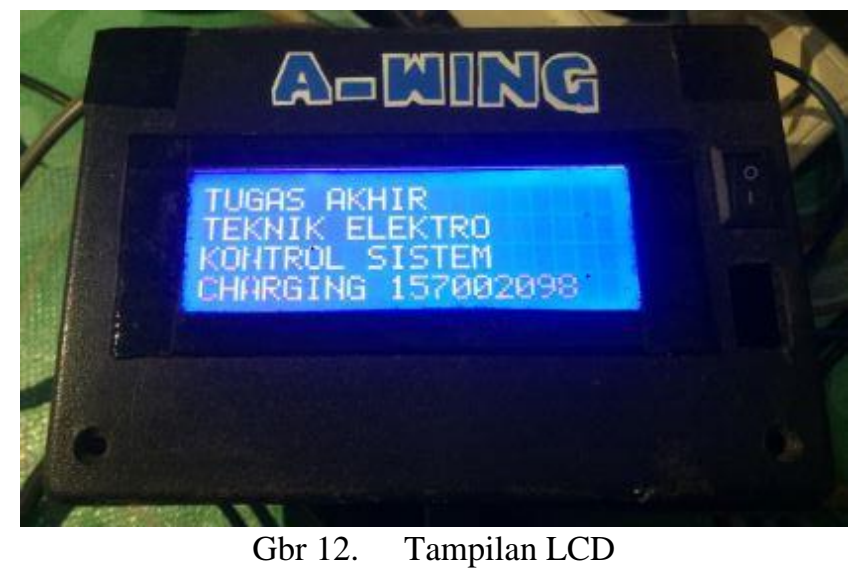

3) Pengujian Sensor Tegangan DC

Gbr 13, merupakan pengujian pada sensor tegangan DC dapat berfungsi dengan baik. Dimana grafik yang disajikan tidak begitu besar nilai errornya, sehingga nilai error pada sensor tidak lebih dari $10 \%$. 

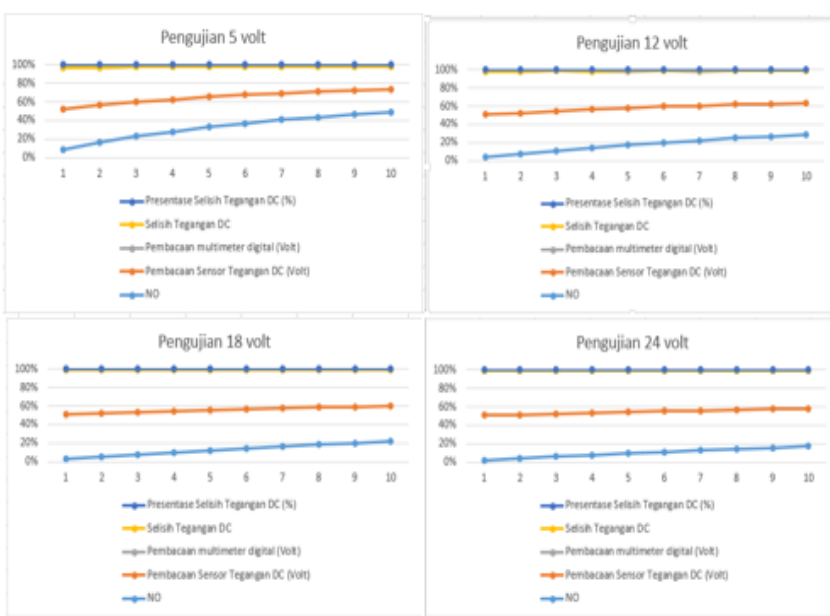

Gbr 13. Grafik Uji Sensor Tegangan DC

\section{4) Pengujian Sensor Arus DC}

Gbr 14, merupakan pengujian pada sensor arus DC dapat berfungsi dengan baik sehingga nilai error pada sensor tidak lebih dari $10 \%$.

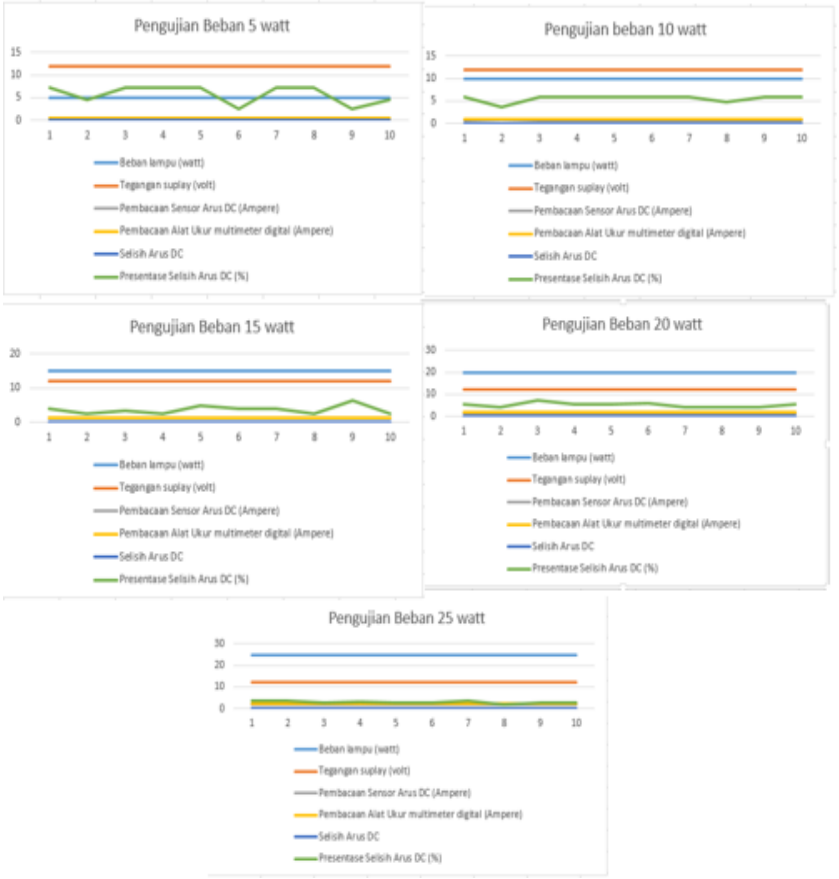

Gbr 14. Grafik Uji Sensor Arus DC

\section{5) Pengujian Modul SD Card}

Gbr 15, merupakan rangkaian Pengujian modul SD card yang dilakukan untuk mengetahui bahwa modul SD card dapat terhubung dan menyimpan data ke micro SD dengan baik serta sesuai instruksi

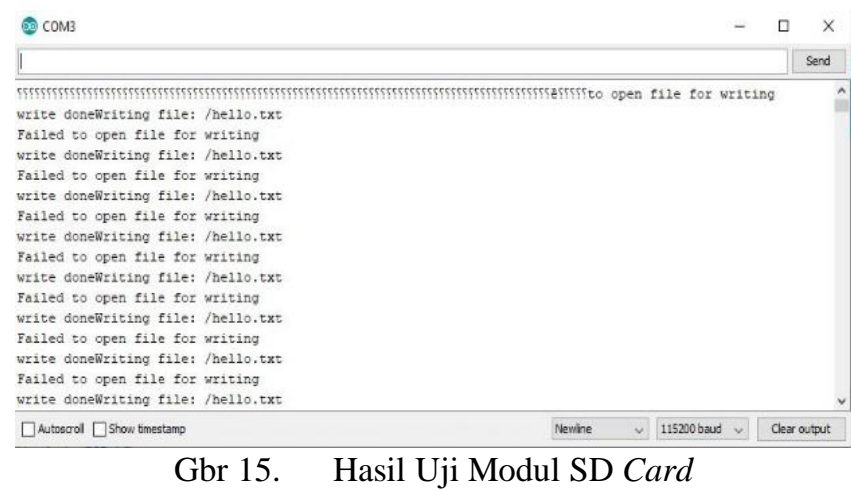

\section{Pengujian Keseluruhan Kontrol Sistem Charging}

Tujuan pengujian sistem pada kontrol sistem charging pembangkit listrik tenaga bayu ini adalah untuk memproleh data charging pada baterai dan memudahkan dalam mengakses data melalui jarak jauh. Pengujian yang meliputi perbacaan sensor, pengujian menampilkan data secara realtime.

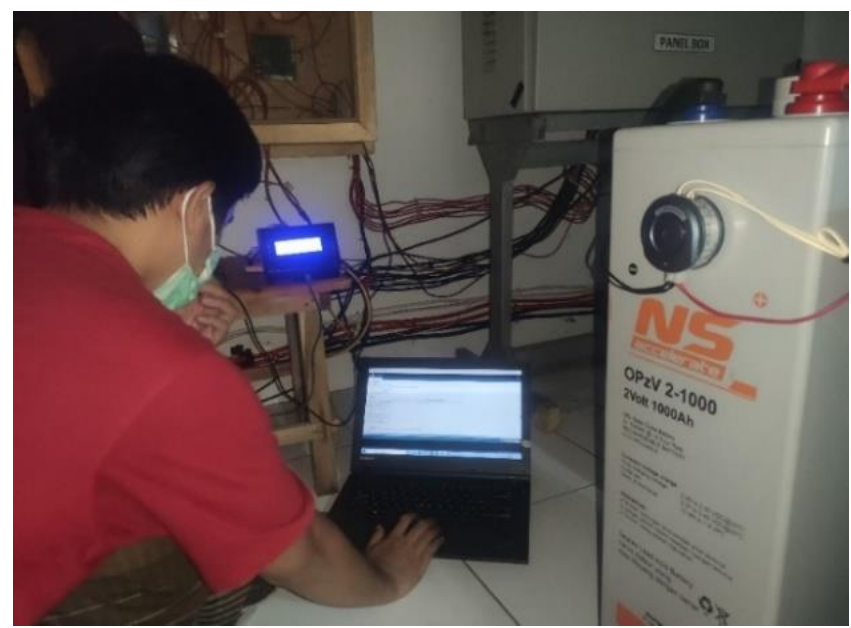

Gbr 16. Pengujian Keseluruhan Kontrol Sistem Charging

Gbr 16, merupakan pengujian keseluruhan meliputi pembacaan sensor tegangan DC yang mengukur tegangan baterai dan untuk sensor arus DC menggunakan modul sensor ACS758 yang berfungsi untuk mengukur arus DC. Sedangkan untuk daya yang diperoleh didapat dari perhitungan tegangan dengan arus yang terukur. Pengujian ini dilakukan di PT. Lentera Bumi Nusantara. Media yang digunakan dalam pengujian ini berupa wind turbine AWING $500 \mathrm{Wp}$ dan baterai pembangkit.

Perekaman data kontrol sistem charging memanfaatkan jaringan internet sebagai penghubung yang nantinya data dengan mudah didapat melalui tampilan website dengan kode sebagai alamat server. Tampialan data dari hasil 
pengukuran selama 24 jam pengukuran bisa dilihat pada Gbr 17.
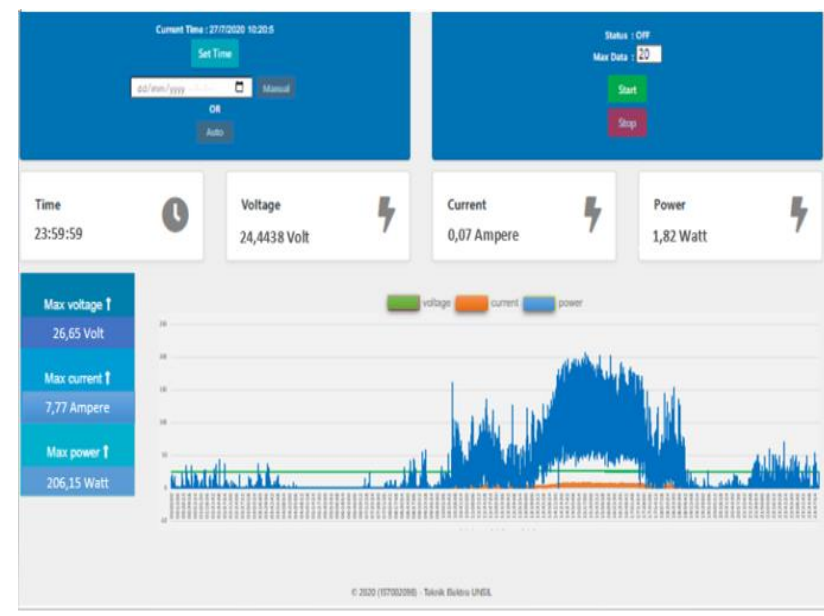

Gbr 17. Tampilan Data Pada Halaman Website

Hasil dari pengujian kontrol sistem charging selama 24 jam pengukuran menghasilkan angka dan grafik dari hasil pembacaan sensor yang terpasang pada kontrol sistem charging, dimana data yang terbaca memiliki kenaikan dan penurunan tergantung dari kecepatan angin yang berhembus pada kincir angin. Selain dari pada itu dengan adanya kontrol sistem charging baterai menjadi terkontrol. Kemudian data tersebut akan tersimpan pada micro SD untuk memudahkan dalam menganalisa data yang terukur, Data dari micro SD dapat dilihat pada Gbr 18, Gbr 19, dan Gbr 20.

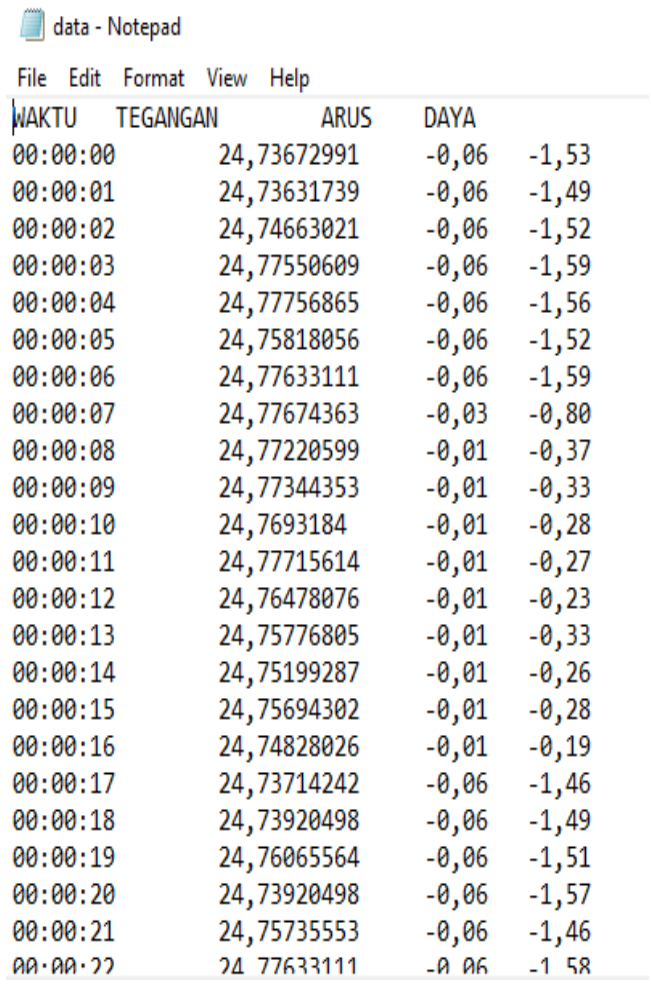

Gbr 18. Data Awal Pada Micro SD

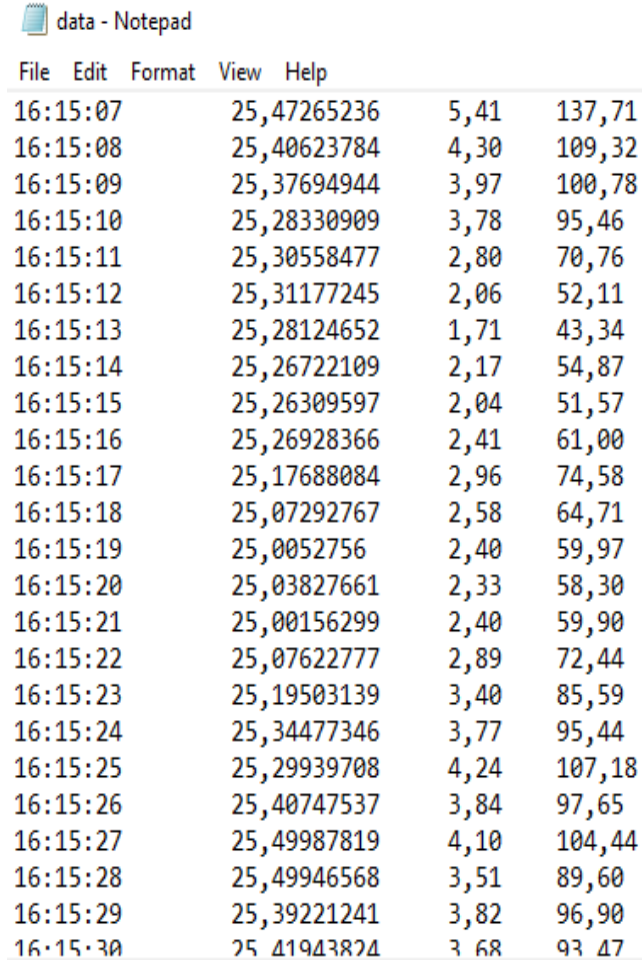

Gbr 19. Data Kenaikan Pada Micro SD

$\begin{array}{llll}\text { Data - Notepad } & & & \\ \text { File Edit Format } & \text { View Help } & & \\ 23: 59: 39 & 24,51314808 & -0,04 & -1,04 \\ 23: 59: 40 & 24,50943547 & -0,02 & -0,57 \\ 23: 59: 41 & 24,51067301 & -0,03 & -0,63 \\ 23: 59: 42 & 24,48880984 & 0,02 & 0,56 \\ 23: 59: 43 & 24,46694667 & 0,08 & 1,95 \\ 23: 59: 44 & 24,45003366 & 0,12 & 3,04 \\ 23: 59: 45 & 24,46983426 & 0,19 & 4,62 \\ 23: 59: 46 & 24,45828391 & 0,26 & 6,33 \\ 23: 59: 47 & 24,44797109 & 0,20 & 4,87 \\ 23: 59: 48 & 24,48262215 & 0,06 & 1,46 \\ 23: 59: 49 & 24,52181085 & -0,03 & -0,68 \\ 23: 59: 50 & 24,47643446 & 0,00 & -0,03 \\ 23: 59: 51 & 24,52511095 & -0,03 & -0,80 \\ 23: 59: 52 & 24,52552346 & 0,07 & 1,72 \\ 23: 59: 53 & 24,52717351 & 0,09 & 2,24 \\ 23: 59: 54 & 24,49664758 & 0,07 & 1,66 \\ 23: 59: 55 & 24,5007727 & 0,05 & 1,23 \\ 23: 59: 56 & 24,50489783 & 0,05 & 1,20 \\ 23: 59: 57 & 24,48592225 & 0,06 & 1,54 \\ 23: 59: 58 & 24,46158401 & 0,06 & 1,46 \\ 23: 59: 59 & 24,44384597 & 0,07 & 1,82\end{array}$

Gbr 20. Data Penurunan Pada Micro SD 


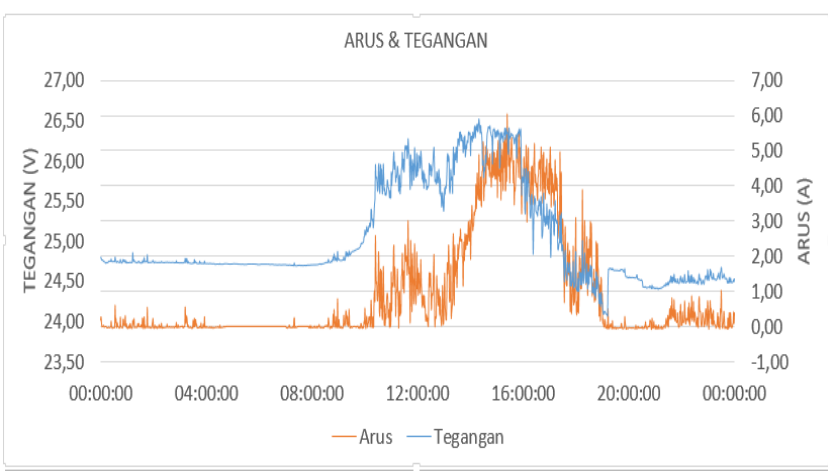

Gbr 21. Grafik Tegangan Dan Arus DC

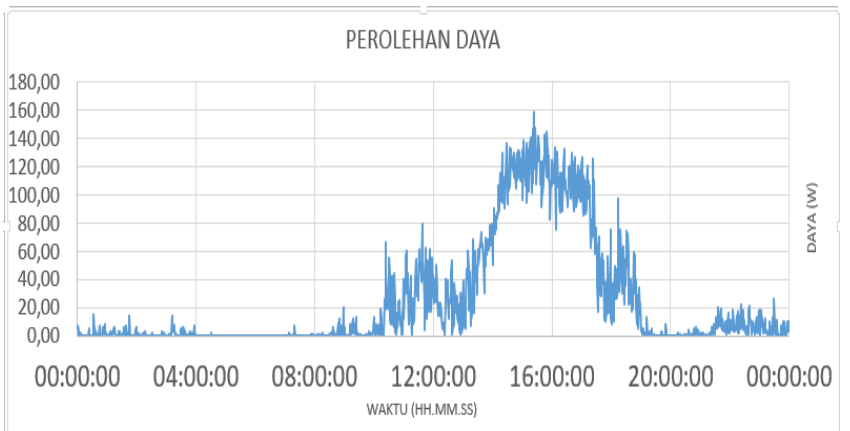

Gbr 22. Grafik Daya

Gbr 22, Menunjukan pengukuran selama 24 jam bahwa nilai tegangan dan arus pada baterai pada saat pukul 00:00:00-09:00:00 perubahan nilai tegangan dan arus memiliki kenaikan yang kurang signifikan karena kecepatan angin pada saat itu sangat kecil. Sehingga, berpengaruh terhadap baterai pembangkit untuk tegangan dan arus menjadi kecil. Sedangkan untuk pukul 11:00:00-20:00:00 perubahan nilai tegangan dan arus memiliki peningkatan yang begitu signifikan karena pada saat itu angin sedang bertiup kencang makan berpengaruh pada nilai tegangan dan arus yang memiliki nilai perubahan yang cukup besar. Kemudian pada saat pukul 19:00:00-00:00:00 perubahan nilai tegangan dan arus memiliki penurunan dimana angin yang bertiup mulai berkurang pada saat itu. Dari nilai tegangan dan arus kemudian di dapat nilai daya untuk grafik nilai daya pada baterai bisa dilihat pada Gbr 23, dengan kata lain nilai daya yang di tampilkan tidak jauh berbeda dengan perubahan pada grafik tegangan dan arus.

\section{Pembahasan Hasil Pengujian}

Pembahasan ini untuk melihat seberapa besar keberhasilan implementasi kontrol sistem charging secara keseluruhan. Pengujian ini dilaksanakan selama 24 jam dengan total pengiriman data 86.400 detik, yang terdiri dari 3 nilai besaran listrik yang terukur yaitu tegangan, arus, dan daya. Tampilan data yang terukur menggunakan layanan internet sehingga, dapat dilihat secara keseluruhan pada tampilan website yang terhubung pada kontrol sistem charging. Selain itu data tersimpan secara otomatis pada micro SD. Daya yang masuk pada baterai bernilai absolut, nilai absolut didapat dari nilai sebenarnya tegangan dan arus yang diperoleh atau tegangan dan arus yang bernilai tidak () jadi nilai tegangan dan arus yang masuk bernilai (+).
Media yang menjadi bahan penelitian yaitu wind turbine A-WING dan baterai yang menjadi penyimpanan tegangan dan arus yang di hasilkan oleh wind turbine. Dari hasil semua pengujian mengacu pada rumusan masalah serta pada tujuan yang ingin dicapai yang pertama yaitu kontrol sistem charging ini dapat memperoleh data yang nantinya masuk pada baterai kemudian yang kedua yaitu kontrol sistem charging ini dapat memudahkan dalam mengontrol baterai melalui jarak jauh. Tampilan data kontrol sistem charging secara realtime dapat dilihat pada display LCD dan pada website secara bersamaan dengan menggunakan jaringan internet yang terhubung. Penelitian ini di laksanakan pada tanggal 25 November 2020 dengan tipe bilah taperless Panjang $90 \mathrm{~cm}$. Data yang terukur berupa tegangan, arus dan daya yang terdapat pada baterai. Data yang diambil dari pembacaan kontrol sistem charging selama 24 jam pengukuran didapat nilai maksimum, minimum dan rata-rata besaran listrik yang terukur secara keseluruhan seperti pada Tbl 1.

\begin{tabular}{|c|c|c|c|}
\hline \multirow{3}{*}{$\begin{array}{c}\text { Charging } \\
\text { Measurement }\end{array}$} & $\begin{array}{l}\text { Max. Battery } \\
\text { Voltage }\end{array}$ & 26,65 & Volt \\
\hline & $\begin{array}{l}\text { Min. Battery } \\
\text { Voltage }\end{array}$ & 23,92 & Volt \\
\hline & $\begin{array}{l}\text { Max. } \\
\text { Charging } \\
\text { Current }\end{array}$ & 7,77 & Ampere \\
\hline \multirow{3}{*}{$\begin{array}{c}\text { Charging } \\
\text { Power }\end{array}$} & $\begin{array}{l}\text { Average } \\
\text { Charging } \\
\text { Wattage }\end{array}$ & 24,48 & Watt \\
\hline & $\begin{array}{l}\text { Max. } \\
\text { Charging } \\
\text { Wattage }\end{array}$ & 206,15 & Watt \\
\hline & $\begin{array}{l}\text { Obtained } \\
\text { Power }\end{array}$ & 587,32 & Wh \\
\hline
\end{tabular}

Data yang ditampilkan pada Table 1. memiliki nilai maksimum dan minimum pada setiap besaran listrik yang terukur oleh kontrol sistem. Pada charging measurement mempunyai nilai besaran listrik sebagai berikut. Untuk tegangan mempunyai nilai maksimum sebesar 26,65volt sedangkan untuk nilai minimumnya sebesar 23,92volt dan mempunyai nilai charging current maksimum sebesar 7,77Ampere untuk arus. Kemudian untuk charging power memiliki 3 nilai yaitu yang pertam nilai Average Charging Wattage sebesar 24,48watt, nilai Maximum Charging Wattage sebesar 206,15watt dan Obtained Power sebesar 587,32 wh. Sehingga kita dapat mengetahui nilai data absolut yang terukur pada kontrol sistem charging.

\section{KESIMPULAN}

Kontrol sistem charging Pembangkit Listrik Tenaga Bayu PT. Lentera Bumi Nusantara berbasis Internet of Things (IoT) didapat kesimpulan dalam proses mendapatkan data kontrol sistem charging pada baterai wind turbine secara realtime melalui jarak jauh, keberhasilan dibuktikan dengan kontrol sistem charging dapat mengirimkan data perubahan baterai pada website yang menampilkan angka dan grafik dengan mengakses ip adress menggunakan laptop 
atau handphone, selama 24 jam kontrol. Sehingga, kontrol sistem charging ini dapat memudahkan kontrol pada pengisian beterai melalui jarak jauh.

\section{REFERENSI}

[1] I. N. Zahra, "Pengenalan Teknologi Pemanfaatan Energi Angin," Pengenalan Teknol. Pemanfaat. Energi Angin, vol. 1, pp. 1-4, 2008.

[2] A. H. Ikhwanul Ikhsan, "Analisis Pengaruh Pembebanan Terhadap Kinerja Kincir Angin Tipe Propeller Pada Eind Turbine Sederhana," 2011.

[3] A. Bachtiar and W. Hayyatul, "Analisis Potensi Pembangkit Listrik Tenaga Angin PT. Lentera Angin Nusantara (LAN) Ciheras," J. Tek. Elektro ITP, vol. 7, no. 1, pp. 34-45, 2018, doi: 10.21063/jte.2018.3133706.

[4] B. Chaniago and A. Hamzah, "Analisa dan Desain Monitoring Pembangkit Listrik Tenaga Angin dengan Menggunakan Web dan Arduino," vol. 5, pp. 1-6, 2018.

[5] H. Piggott, T. Kirby, and H. Piggott, "Wind power Workshop Windpower Workshop BUilding Your Own Wind Turbine."

[6] N. Hiron, A. Andang, and H. Setiawan, "Batch Processing Method in Machine to Machine Wireless Communication as Smart and Intelligent System," Int. J. Futur. Comput. Commun., vol. 5, no. 3, pp. 163-166, 2016, doi: 10.18178/ijfcc.2016.5.3.464.

[7] D. J. Ayub Subandi, "Sistem Pemantauan Pembangkit Listrik Tenaga Angin Berbasis Mikrokontroler Dan Website," no. November, pp. 41-52, 2015.

[8] Y. Efendi, "Internet Of Things (Iot) Sistem Pengendalian Lampu Menggunakan Raspberry Pi Berbasis Mobile," J. Ilm. Ilmu Komput., vol. 4, no. 2, pp. 21-27, 2018, doi: 10.35329/jiik.v4i2.41.

\section{BIOGRAFI PENULIS}

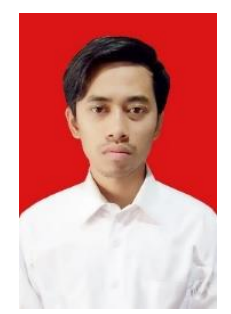

Angga Laksana, Lahir pada tanggal 14 januari 1996 di Kabupaten Pandeglang, Banten. Sedang menempuh studi S1 sejak tahun 2015 di Universitas Siliwangi, Fakultas Teknik Prodi Teknik Elektro. 